\title{
Prospects for Cooperative Marketing among Surgical Instrument Producers in Pakistan
}

\section{Theresa Thompson Chaudhry*}

\begin{abstract}
:
Given that clustered firms in developing countries generally sell their goods through multinational firms, we seek to determine under what conditions might clustered surgical instrument firms band together and form a cooperative to "break out" of their relationship with multinational buyers to market their own goods. Our results, based on a survey of surgical instrument producers in Sialkot, Pakistan, demonstrate that firms are more likely to be interested in such initiatives once they have already had some direct experience in marketing, such as selling products under their own brand name and having already sold some goods directly to hospitals. Firms that have had relationships of longer duration with customers tend to be less likely to be interested in joint action initiatives. This indicates that a higher opportunity cost of engaging in joint action (as proxied by relationships of longer duration) reduces the likelihood of cooperative marketing initiatives in clusters.
\end{abstract}

Keywords: Surgical instruments, goods, cooperative, market, Pakistan.

JEL Classification: D24, M31, J54.

\section{Introduction}

An industrial cluster consists of a group of firms that are specialized by sector, located in close geographic proximity and composed mainly of small and medium-sized enterprises. Industrial clusters have been viewed as important in developing countries due to the significant contributions they make to their economies through the

\footnotetext{
${ }^{*}$ Associate Professor, Department of Economics, Lahore School of Economics, Pakistan.
} 
generation of employment, output, and exports. ${ }^{1}$ In the literature on clusters, some authors have termed the benefits of agglomeration active and passive collective efficiency. Passive collective efficiencies, such as market access, access to a large pool of skilled labor, technological spillovers, flexible specialization (vertical disintegration), and reduced transaction costs, are enjoyed by firms by virtue of their location within the cluster. On the other hand, active collective efficiencies require purposeful cooperation between the firms of the cluster to upgrade production, also called "joint action." 2 In this study, we wish to understand which firm and cluster characteristics contribute to firms' interest in intra-cluster cooperation to engage in a joint marketing initiative to sell their own goods, a form of active collective efficiency.

Given that industrial clusters in developing countries export the majority of their output through middlemen in developed countries, some authors express concern that these small manufacturers will remain as low value added producers while the multinationals designing, marketing, and retailing will keep the larger share of the profits (Schmitz, 1999). On the other hand, the proximity of clustered firms (both geographic and cultural) may provide a unique opportunity for small and medium sized firms to assert their interests and collectively market their goods in the world market.

This study provides an empirical analysis to determine which factors influence the decision of exporting firms in Sialkot's surgical instrument cluster to engage in a hypothetical joint venture that would allow them to market their own goods. Cooperation among the clustered firms may be necessary since many are too small individually to make the investments required to successfully market and distribute their output in a developed country market. This analysis will help to shed light on the ability of other, similar clusters to undertake initiatives of this type. We find that exporters with some previous experience in direct marketing are more interested in a consortia with other firms to market goods. On average, firms with a long trading relationship with its oldest customer

\footnotetext{
${ }^{1}$ Clusters produce a significant amount of output, with a great deal of this output bound for the export market. For example, India's Palar Valley clusters produce forty-five percent of the country's leather, where there are at least 600 tanneries in five clusters. In Tirruppur, India, there were at least 2000 clustered cotton knitwear firms in 1995, which produced about 70 percent of India's exports of this commodity (Banerjee and Munshi (2000)). In Ludhiana, India, there were 10,000 firms and 200,000 workers producing Rs 241 billion (almost $\$ 10$ billion in U.S. 1991 dollars) of woolen knitwear in 1991 (Tewari (1999)). In Agra, India, 5000 clustered firms were producing 300,000 pairs of shoes per day in 1991-92 (Knorringa (1999)).

${ }^{2}$ Schmitz and Nadvi (1999), pg. 1504.
} 
tend to express less interest in joint marketing agreements, most likely due to the fact that longer duration trading relationships are of high (and certain) value. Interest in joint marketing was unrelated to firm size, age, or utilization of bank credit.

In this paper, we attempt to determine whether firm level characteristics affect the decision of exporting firms to engage in a joint action marketing initiative. In other words, we determine which factors contribute to the exporting firms deciding to join together to collectively market their own goods rather than sell their output through a middleman. The rest of the paper will proceed as follows. Section 2 will discuss some of the relevant literature pertaining to clusters and joint marketing among firms. In Sections 3 and 4, we describe Sialkot's surgical instrument cluster and the design of the survey conducted there. The empirical model is set up in Section 5 and the results presented in Section 6. Section 7 concludes.

\section{Literature Review}

There is a substantial case study literature on clusters in developing countries including Brazil, India, Mexico, Pakistan, and Peru. These studies are mainly descriptive, highlighting the perceived benefits of clustering, both passive and active. Often, these studies stress the role of active cooperation among clustered firms that are jointly facing problems ranging from trade liberalization, loss of markets, and new quality and environmental standards (Kennedy (1999), Nadvi (1999a), Rabellotti (1999), Tewari (1999)). In addition, some have suggested that clustered firms may be able to cooperate in order to "break out" of the relationship with foreign buyers and carry out their own design and marketing in order to gain a greater share of producer surplus (Humphrey and Schmitz (2000), Kaplinsky (2000), Schmitz (1999)). Success in this respect has been mixed. Clustered shoe producers in Brazil were able to penetrate regional but not international markets in the design, distribution and marketing of output (Schmitz (1999)).

Rabelloti (1999) focused on the Guadalajara cluster in Mexico, and in particular how inter-firm relationships had been affected by increased competition after trade liberalization. She found firm performance to be positively correlated with inter-firm cooperation, both horizontal (with fellow manufacturers) and vertical (with suppliers), although the survey instruments were not wholly objective measures. 
Schmitz (1999) examined the successes and failures of cooperative behavior in the 1980s and 1990s among Brazilian firms operating in Sinos Valley footwear cluster. Greater cooperation between manufacturers and intermediate input producers enabled improvements in the quality of goods, decreased delivery times and smaller batch sizes, in accordance with the changing demands of foreign buyers from the U.S. Starting in the late 1980s, increased competition from China for U.S. buyers put pressure on the firms in the cluster. The "Shoes from Brazil Program," a major joint action initiative to improve marketing abroad, failed because the largest five exporting firms (that were vertically integrated and had a close relationship with the largest U.S. buyer) undermined the plan, using their influence in the shoe manufacturers' association, Abicalcados. ${ }^{3}$

Cooperative marketing has been fairly extensively studied in agricultural settings. Also, in the management and marketing literature, there have been discussion papers on cooperative strategies (including marketing arrangements) within "fragmented industries" (Dollinger (1990)) and documentation of joint marketing arrangements among retailers and manufacturers (Dickinson and Ramaseshan (2008)). In industrial settings, however, there is little economic literature on this specific subject. The studies of joint ventures in industrial organization tend to focus on issues of transaction costs and residual rights of ownership for evaluating the optimality of investment levels achieved (Bai et al (2004), Cai (2003)). One exception is Kogut (1988), who studied the stability of joint venture agreements in the U.S., finding no relationship between joint marketing/distribution and the break-up of joint ventures.

Thompson (2005) developed a theoretical model of "joint action" for clustered firms to cooperatively market their own goods. It examined the conditions under which clustered firms in a developing country, heterogeneous in their expected quality of output, could functionally upgrade through cooperation to eliminate a foreign distributor from a developed country acting as an intermediary between the clustered manufacturers and the final market for the goods. The model proved that joint action can potentially occur among high quality type firms, but that low quality firms would continue to export through a middleman. An important determinant of whether joint action occurs is the opportunity cost of such initiatives, as determined by the prices that the middleman is willing to pay for the cluster's goods. The model also showed that joint action is more likely to take place when i) the size of the cluster, the

\footnotetext{
${ }^{3}$ Schmitz (1998), p 34.
} 
probability of producing high quality output by the high type firms, and the final market price of the good are high, and ii) when the probability of producing high quality by the low type firms and the marketing cost are low. While the high quality firms do not need to be in the majority for cooperative marketing to succeed, a critical mass of high quality firms (the size of which depends on the parameter values) must exist as a necessary condition.

There is a small literature on industrial clusters in Pakistan, focusing primarily on the Sialkot surgical goods cluster. Nadvi (1999) documented the reaction of firms to actions by the U.S. Food and Drug Administration to halt imports from Sialkot on quality and safety grounds, leading to increased acquisition of ISO certifications by the cluster. Ilias (2001) focused on the role of family labor in Sialkot, concluding that there existed a labor market distortion such that family managers were preferred to non-family and therefore firm output was correlated with family size. Thompson (2005) and Chaudhry (2011) examined the relational aspects of inter-firm trust and switching costs respectively.

\section{Description of the Sialkot's Surgical Instrument Sector}

In Sialkot (Punjab, Pakistan), a cluster of surgical instrument manufacturers operates, consisting of approximately 230 producers and 2000 subcontracting firms (see Table 1). The cluster produces around 10,000 different varieties of surgical, veterinary, and manicuring instruments mainly for foreign markets including the United States and Western Europe, with three-quarters of the cluster's output destined for these two regions. ${ }^{4}$ While the U.S. mainly imports Sialkot's disposable instruments, Europe principally imports the re-useable variety. ${ }^{5}$ This output of the cluster is economically important, as it produces approximately 150,000 pieces annually with the value of production estimated at Rs 22 billion. ${ }^{6}$

Within the cluster, the production process typically takes place in stages. Other than the largest manufacturers, production of a final good is not carried out in a single firm. A large number of small firms that specialize in one or more stages of the production process constitute the vendor segment. On the other hand, larger firms sub-contract out few processes, and that the largest firms carry out $80-90$ percent of production

\footnotetext{
${ }^{4}$ SMEDA (2001), pg 16, pg. 21.

${ }^{5}$ SMEDA (2001), pg. 17.

${ }^{6}$ LUMS (2010), pg. 172.
} 
processes in-house. ${ }^{7}$ The cluster also has local business associations, including the Metal Industries Development Centre, the Sialkot Dry Port Trust, the Sialkot Chamber of Commerce and Industry (SCCI) and the Surgical Instrument Manufacturer's Association (SIMA).

Table 1: Surgical Instrument Firms in Pakistan

\begin{tabular}{lllll}
\hline $\begin{array}{l}\text { Size of } \\
\text { Firm }\end{array}$ & $\begin{array}{c}\text { Number of } \\
\text { Firms }\end{array}$ & $\begin{array}{c}\text { Number of } \\
\text { Employees }\end{array}$ & $\begin{array}{c}\text { Revenues } \\
\text { (Pakistan Rupees) }\end{array}$ & $\begin{array}{c}\text { Capital } \\
\text { (Pakistan Rupees) }\end{array}$ \\
\hline Large & 30 & $250-400$ & Rs 60-100 million & Rs 50-100 million \\
Medium & 50 & $100-250$ & Rs 10-60 million & Rs 10-25 million \\
Small & 150 & $30-50$ & Rs 1-10 million & Rs 1-5 million \\
Vendors & 2000 & $5-20$ & Rs 1-1.5 million & Rs 50,000-1 million \\
Traders & $800-1000$ & na & na & Na \\
\hline
\end{tabular}

Source: Board of Investment, Government of Pakistan

The origins of the cluster are quite interesting, having originated more than 100 years ago. Local blacksmiths began producing surgical instruments around the start of the $20^{\text {th }}$ century at the request of the American Mission Hospital in Sialkot. In the 1930s, the cluster began exporting regionally to countries such as Egypt and Afghanistan, and supplied Allied forces during World War II. The industry expanded after World War II, but strong pro-labor legislation that was passed in 1973 led to dramatically increased labor costs for firms with more than 10 employees, leading the industry to shift to extensive sub-contracting, referred to as "vendorization." 8

Quality concerns have plagued the cluster at times and reached a crisis point in 1994 when the U.S. Food and Drug Administration (FDA) halted imports from Pakistan, which was resolved when the firms adopted Good Manufacturing Practice (GMP) standards (Nadvi, 1999a). Not all firms use the most technologically advanced equipment and processes, as many of the machines have been locally built by means of reverse-engineering techniques. Again, the largest companies contrast with the smaller firms in that they tend to utilize more modern equipment. Nonetheless, the direct cause of the difficulties with the FDA were problems with the alloy composition of locally manufactured steel used for the disposable instruments, a problem that was accentuated by

\footnotetext{
${ }^{7}$ SMEDA (2001), pg. 39.

${ }^{8}$ SMEDA (2001), pg. 9 and pg. 52.
} 
the lack of proper testing facilities.9,10 Even after many Sialkot firms obtained GMP certificates, the firms continued to only have access to an outdated facility to test steel composition.

\section{Description of the Survey Instrument}

For purposes of this study, we designed and commissioned a survey of the surgical instrument cluster in Sialkot, Pakistan. However, when the interviewer (from a local university) visited the cluster, she found that only about 180 of the 220 exporting firms that were listed by SIMA (the local business association) were actually in operation at that time. Of these, 76 exporters at least partially completed the questionnaire, resulting in a 43 percent response rate.

The survey covered several aspects of the exporters' interactions with other firms, including relationships with its customers and suppliers. One portion of the survey dealt (which will be utilized here) with firms' current efforts at direct sales to hospitals and doctors, and the firms' interest in joint marketing initiatives. This section of the questionnaire can be found in Annex 1.

Table 2: Current Marketing Strategies

\begin{tabular}{lccc}
\hline & $\begin{array}{c}\text { Sales Under Your } \\
\text { Own Name }\end{array}$ & $\begin{array}{c}\text { Any Direct Sales to } \\
\text { Hospitals }\end{array}$ & $\begin{array}{c}\text { Internet } \\
\text { Marketing }\end{array}$ \\
\hline Yes & $55.4 \%$ & $69.6 \%$ & $71.4 \%$ \\
No & $44.6 \%$ & $30.4 \%$ & $28.6 \%$ \\
Number of & 56 & 56 & 56 \\
Observations & & & \\
\hline
\end{tabular}

With respect to the firms' current marketing strategies, nearly half of firms sell some products under their own name, and about 30 percent of firms engage in direct sales to hospitals (Table 2). An equal share engage in some direct sales through the internet. Appendix Tables 1 and 2 break these down by firm size (measured by employment) and firm age, but no clear pattern emerges.

From the survey, we know that thirty firms state that the idea of joint marketing has in fact already been discussed among exporters in Sialkot. The other questions dealt with the firms' interest in a hypothetical

\footnotetext{
${ }^{9}$ SMEDA (2001), pg. 49.

${ }^{10}$ Imported steel is used for the re-usable instruments.
} 
joint marketing initiative (Tables $3 a, 3 b$, and $3 c$ ). Interest was generally low, with just over a quarter of firms displaying some interest in a joint venture of this type. Of those potentially interested, about half of the firms would require a 25 to50 percent increase in prices paid to entice them to join. Stricter quality requirements from current customers (which would lower the value of the current relationship) led to similar answers, with slightly less than one-fourth of firms responding affirmatively. About one-third of firms would be more amenable to joint marketing if the majority of participating firms were large, while a similar share showed preference toward a joint venture with small firms. Looking at the breakdown by firm size, firms tended to favor a joint venture with other firms of the same size as them. This is consistent with other literature on joint ventures including Human and Provan (1997) and Saxton (1997). In Human and Provan (1997), alliance success appeared to be loosely correlated with the homogeneity of the alliance members. Saxton (1997) found subjective satisfaction with alliances to be positively correlated with structural similarities with a partner. Dickson and Weaver (1997) found a small positive correlation between alliance use and firm size.

More firms - over half - showed interest in direct sales through the internet. Overall, judging from Appendix Tables 1 and 2, the larger firms appear to be less interested in joint marketing, but more so in direct sales through the internet as compared to the small and medium sized firms. No clear patterns emerge with respect to these variables and firm age.

Tables 3a, 3b, and 3c: Interest among Exporters in Direct Sales and Joint Marketing.

Table 3a: General Interest in Joint Marketing, Conditional on Output Price

\begin{tabular}{lc}
\hline & Percent \\
\hline Not interested in joint marketing & 73.2 \\
Yes, if 50\% price increase & 5.4 \\
Yes, if 25\% price increase & 7.1 \\
Yes, if 10\% price increase & 8.9 \\
Yes, even if no price increase & 5.4 \\
Number of Observations & 56 \\
\hline
\end{tabular}


Table 3b: Interest in Joint Marketing, Conditional on Reactions of Existing Customers

\begin{tabular}{|c|c|c|}
\hline & $\begin{array}{c}\text { If Higher Quality } \\
\text { Standards } \\
\text { Imposed }\end{array}$ & $\begin{array}{c}\text { Interest in } \\
\text { Direct Internet } \\
\text { Sales }\end{array}$ \\
\hline Not interested in joint marketing & $71.4 \%$ & $42.9 \%$ \\
\hline Yes, if don't lose current customers & $7.1 \%$ & $30.4 \%$ \\
\hline Yes, even if lose current customers & $14.3 \%$ & $16.1 \%$ \\
\hline No Answer & $7.1 \%$ & $10.7 \%$ \\
\hline Number of Observations & 56 & 56 \\
\hline \multicolumn{3}{|c|}{$\begin{array}{l}\text { Table 3c: Interest in Joint Marketing, Conditional on Size of Other } \\
\text { Firms in Co-op }\end{array}$} \\
\hline & $\begin{array}{l}\text { If Mostly Large } \\
\text { Firms in Co-op }\end{array}$ & $\begin{array}{l}\text { If Mostly Small } \\
\text { Firms in Co-op }\end{array}$ \\
\hline More interested in joint marketing & $32.1 \%$ & $28.6 \%$ \\
\hline Not more interested & $62.5 \%$ & $67.9 \%$ \\
\hline No Answer & $5.4 \%$ & $3.6 \%$ \\
\hline Number of Observations & 56 & 56 \\
\hline
\end{tabular}

\section{Framework for Analysis}

Probit regression techniques are used to determine how firm-level characteristics affect the decision of an exporting firm to engage in joint action to market their own goods. The dependent variable comes from the survey question asking about the exporting firms' interest in a hypothetical joint marketing initiative.

Drawing from the theoretical model developed by Thompson (2005), we hypothesize that the value of the firm's current trading relationship will be an important determinant of interest among firms in joint marketing. Specifically, the higher the value of the current trading relationship, the less likely will firms be to want to endanger it by enlisting alternate marketing channels. Other firm characteristics that could potentially influence the proclivity of exporters to engage in a joint action initiative to market their own goods include risk aversion, access to credit (as a source of funds to set up the project), and previous experience of the firm with direct marketing. Summary statistics for each of these variables can be found in Appendix Table 3. We estimate the following equation: 


$$
P_{i}=\alpha+\beta E_{i}+\gamma R_{i}+\delta D_{i}+\phi Z_{i}+\varepsilon_{i}
$$

where:

E: Experience with direct marketing

$R$ : Relationship with other firms

$D$ : Opportunity cost of joint marketing

\section{Z: Firm level controls}

Previous experience in direct marketing is measured by two dummy variables that the firms have sold products under their own name and have sold some goods directly to hospitals. A prediction about the likely impact of previous experience with marketing is not immediately apparent. The existing literature on alliances between firms (for marketing among other joint ventures) indicates that previous experience with alliances contributes positively to the likelihood of future alliances (Gulati, 1995; Saxton, 1997). However, it says little about the effect of previous experiences in direct marketing on such cooperatives. Previous experiences with direct marketing will provide those firms with better information about both the costs and benefits of direct marketing. On the one hand, firms that have had some marketing experience might be more likely to be interested in expanding their efforts through a larger and broader joint marketing initiative if their past experience proves that the costs are high relative to the per firm benefits. On the other hand, if they have already had some success marketing on their own, they may not be interested in sharing their knowledge and experience with the rest of the cluster if the benefits per firm are high relative to the costs of breaking in. Given that we do not have estimates of the per firm costs or benefits of joint marketing, we will proceed without making a prediction for the signs of these coefficients.

Relationships between firms are measured by a dummy variable that firms speak at least weekly with other producers. Frequent interaction with other firms may positively affect a firm's joint marketing decision because this interaction may serve to spread information and help the initiative to gain momentum and support among the cluster firms. We predict that this variable will positively influence the decision of firms to participate in joint marketing. We also predict that access to credit, proxied by use of credit, should positively affect the decision to participate, since 
these firms are more able to fund their participation in the initiative.

On the other hand, a firm's decision to participate in a direct marketing scheme should be inversely related to the value of the firm's trading relationship with its current trading partners. This variable is proxied by the duration of the firm's relationship with its oldest customer. Firms that are more risk averse should also be less likely to be interested in a joint action initiative. The proxies used to measure risk aversion are firm size (number of employees) and firm age. The hypothesis is that larger and older firms are less risk averse and therefore will express greater interest in joint marketing.

\section{Regression Results}

Probit and linear probability regressions are estimated for the probability that firms would decide to participate in the hypothetical joint action initiative, using various firm-level characteristics as explanatory variables as described in the previous sub-section. The results of these regressions are presented in Table 4.

The results show that firms with some previous experience in direct marketing, including selling some products under their own name and selling some goods directly to hospitals, have a greater interest in carrying out a joint venture with other firms for purposes of marketing. In the full probit model, firms that sell products under their own brand name are 26 percent more likely to be interested, and firms that have already sold some goods directly to hospitals are 34 percent more likely to be interested in a joint marketing initiative.

Firms that have had longer duration relationships with customers tend to be less likely to be interested in joint action. Increasing the duration of a firm's relationship with their oldest customer by one year reduces the likelihood that a firm is interested in a joint marketing initiative by about 8 percent. Increasing the duration by one standard deviation (from 11.55 to 20.19 years) reduces the probability that a firm is interested in joint action by nearly 52 percent. These results are consistent with the hypothesis that firms with a higher opportunity cost of joint action would be less likely to participate in such initiatives. Since the coefficient on the duration-squared variable is positive, one may be concerned that the impact of duration on the likelihood of carrying out joint action may become positive for some sample points. However, the median duration of relationship (with the oldest customer) is 10 years, and the effect of duration on joint action only 
becomes positive at 38.5 years, and only one firm has a relationship of duration longer than this value.

Table 4: Joint Action Results, Marginal Effects

\begin{tabular}{|c|c|c|c|c|c|c|}
\hline & Probit & $\begin{array}{l}\text { Probit } \\
\text { Full } \\
\text { Model }\end{array}$ & $\begin{array}{c}\text { Linear } \\
\text { Probability }\end{array}$ & $\begin{array}{l}\text { Probit } \\
\text { (no dur) }\end{array}$ & $\begin{array}{c}\text { Probit } \\
\text { (\% sale) }\end{array}$ & $\begin{array}{l}\text { IV Probit } \\
\text { (For Talk } \\
\text { Weekly) }\end{array}$ \\
\hline $\begin{array}{l}\text { Employment } \\
\text { (in tens) }\end{array}$ & $\begin{array}{l}0.003 \\
(0.18)\end{array}$ & $\begin{array}{l}0.009 \\
(0.38)\end{array}$ & $\begin{array}{c}-0.0003 \\
(-0.03)\end{array}$ & $\begin{array}{l}0.001 \\
(0.05)\end{array}$ & $\begin{array}{l}0.009 \\
(0.48)\end{array}$ & $\begin{array}{l}-0.007 \\
(-0.43)\end{array}$ \\
\hline Employment squared & $\begin{array}{c}-0.0002 \\
(-0.83)\end{array}$ & $\begin{array}{c}-0.0004 \\
(-0.6)\end{array}$ & $\begin{array}{c}-0.0001 \\
(-0.56)\end{array}$ & $\begin{array}{c}-0.0002 \\
(-0.7)\end{array}$ & $\begin{array}{l}-0.001 \\
(-1.0)\end{array}$ & $\begin{array}{c}-1.4 \mathrm{E}-05 \\
(-0.05)\end{array}$ \\
\hline Age & $\begin{array}{l}-0.013 \\
(-0.8)\end{array}$ & $\begin{array}{l}0.023 \\
(1.16)\end{array}$ & $\begin{array}{l}0.021 \\
(0.79)\end{array}$ & $\begin{array}{l}-0.009 \\
(-0.59)\end{array}$ & $\begin{array}{l}0.034 \\
(1.54)\end{array}$ & $\begin{array}{l}0.053 \\
(1.61)\end{array}$ \\
\hline Age squared & $\begin{array}{c}0.0004 \\
(1.09)\end{array}$ & $\begin{array}{l}-0.0002 \\
(-0.62)\end{array}$ & $\begin{array}{l}-0.0002 \\
(-0.36)\end{array}$ & $\begin{array}{l}0.0003 \\
(0.82)\end{array}$ & $\begin{array}{c}-0.0004 \\
(-0.88)\end{array}$ & $\begin{array}{l}-0.001 \\
(-1.16)\end{array}$ \\
\hline $\begin{array}{l}\text { Sell some products } \\
\text { under own name }\end{array}$ & $\begin{array}{l}0.250^{*} \\
(2.01)\end{array}$ & $\begin{array}{c}0.257+ \\
(1.95)\end{array}$ & $\begin{array}{c}0.238+ \\
(2.01)\end{array}$ & $\begin{array}{l}0.256^{*} \\
(1.99)\end{array}$ & $\begin{array}{c}0.195+ \\
(1.73)\end{array}$ & $\begin{array}{l}0.188 \\
(1.25)\end{array}$ \\
\hline $\begin{array}{l}\text { Sell some products to } \\
\text { hospitals directly }\end{array}$ & $\begin{array}{l}0.267 \\
(1.98)^{*}\end{array}$ & $\begin{array}{l}0.343^{*} \\
(2.34)\end{array}$ & $\begin{array}{l}0.335^{* *} \\
(2.71)\end{array}$ & $\begin{array}{c}0.245+ \\
(1.79)\end{array}$ & $\begin{array}{l}0.321^{*} \\
(2.07)\end{array}$ & $\begin{array}{c}0.324+ \\
(1.93)\end{array}$ \\
\hline $\begin{array}{l}\text { Relationship Duration } \\
\text { - oldest customer } \\
\text { (years) }\end{array}$ & & $\begin{array}{c}-0.077^{* *} \\
(-2.77)\end{array}$ & $\begin{array}{c}-0.076^{* *} \\
(-2.84)\end{array}$ & & $\begin{array}{c}-0.085^{* *} \\
(-2.78)\end{array}$ & $\begin{array}{c}-0.105^{* *} \\
(-3.06)\end{array}$ \\
\hline Duration squared & & $\begin{array}{l}0.002^{* *} \\
(2.71)\end{array}$ & $\begin{array}{l}0.002^{* *} \\
(2.73)\end{array}$ & & $\begin{array}{l}0.002^{* *} \\
(2.96)\end{array}$ & $\begin{array}{l}0.003^{*} \\
(2.63)\end{array}$ \\
\hline Credit Use & & $\begin{array}{l}0.111 \\
(0.89)\end{array}$ & $\begin{array}{l}0.136 \\
(1.19)\end{array}$ & $\begin{array}{l}0.046 \\
(0.33)\end{array}$ & $\begin{array}{l}0.089 \\
(0.91)\end{array}$ & $\begin{array}{l}0.302 \\
(1.45)\end{array}$ \\
\hline $\begin{array}{l}\text { Talk at Least Weekly } \\
\text { with Other Producers }\end{array}$ & & $\begin{array}{l}0.172 \\
(1.37)\end{array}$ & $\begin{array}{c}0.182+ \\
(1.77)\end{array}$ & $\begin{array}{l}0.131 \\
(1.03)\end{array}$ & $\begin{array}{l}0.122 \\
(0.98)\end{array}$ & $\begin{array}{l}0.644 \\
(1.35)\end{array}$ \\
\hline $\begin{array}{l}\text { Percentage Sales to } \\
\text { Oldest Customer }\end{array}$ & & & & & $\begin{array}{l}0.001 \\
(0.78)\end{array}$ & $\begin{array}{l}-0.001 \\
(-0.32)\end{array}$ \\
\hline Observations & 56 & 56 & 56 & 56 & 46 & 46 \\
\hline Prob $>\mathrm{Chi}^{2}$ (or Prob $\left.>\mathrm{F}\right)$ & 0.01 & 0.011 & 0.001 & 0.084 & 0.037 & 0.014 \\
\hline (Pseudo) R-squared & 0.187 & 0.35 & 0.356 & 0.204 & 0.37 & 0.129 \\
\hline
\end{tabular}

(Marginal effects coefficients reported; Robust $\mathrm{z}$ or $\mathrm{t}$ statistics in parentheses, ${ }^{* *}$ significant at $1 \%$, *significant at $5 \%,+$ significant at $10 \%$ )

Having credit, either from a bank or through a credit association has a positive but insignificant effect on the likelihood of being interested in direct marketing. Since the cost of such an initiative was not discussed in the questionnaire, it is possible that the firms did not consider the potential cost when answering the questions about joint action.

Risk aversion (as measured by firm size and age) does not appear to affect the decision to participate in a joint marketing initiative. Intra-cluster 
communication as measured by frequent interactions with other producers, while positive in sign as expected, also had no significant impact.

\subsection{Robustness Checks}

When the full model is estimated as a linear probability model, the results change very little whether in terms of the magnitudes of the coefficients or the statistical significance. The only noticeable impact is on "talk weekly with other producers" which becomes significant at the 10 percent level in the linear probability model.

There was some concern about the high correlation between firm age and duration of relationship with the oldest customer driving the results on the duration variable. However, when duration is dropped from the regression, the age variable still does not gain significance. Adding the percentage of sales to the oldest customer has very little impact, when the duration variable is added back into the regression.

In the final specification, we attempted to instrument for the frequency of inter-firm communication with variables associated with the quality of such interactions, including belief in the strength of informal contract enforcement and the use of social contacts to gain information about customers. The magnitude of the instrumented coefficient rises, but does not gain statistical significance. However, this is not surprising given that the first-stage results were weak.

\section{Conclusions}

Consortia have been proposed by UNIDO and others in order to allow small firms to generate greater bargaining power and achieve greater economies of scale. ${ }^{11}$ UNIDO goes a step further and actively promotes export consortia in a number of countries including Morocco, Peru, Tunisia, and Uruguay, including the upgrading of member firms, joint purchases, promotion of exports and common branding (Antoldi et al, 2009). They find that homogeneity of the group of firms involved is an important factor in success when considering size, sector, and level of internationalization (with complementarities in product offerings also beneficial). Anecdotally they appear to have been successful in achieving these objectives; however, to our knowledge a scientific evaluation (using treatment and control groups) has not yet been implemented.

\footnotetext{
${ }^{11}$ LUMS makes a similar proposal for the fan industry in Gujrat and Gujranwala, Pakistan.
} 
One can imagine that the outlook for joint marketing of goods might be difficult, particularly since the development of a brand name requires vigilance over and uniformity of quality. Indeed, in our survey, the general interest in joint marketing was low at little more than 25 percent. The joint marketing regression results show that exporters with some previous experience in direct marketing, including selling some products under their own name and selling some goods directly to hospitals, are more interested in carrying out a joint action with other firms to market goods. On average, firms with a long trading relationship with its oldest customer tend to express less interest in joint marketing agreements, most likely due to the fact that longer duration trading relationships are of high (and certain) value. 


\section{References}

Antoldi, F., Cerrato, D., and Depperu, D. (2009). The Strategic Management of Export Consortia: An Analysis of the Experience of UNIDO in Morocco, Peru, Tunisia, and Uruguay. Report prepared for UNIDO.

Bair, J., and Gereffi, G. (2001). Local Clusters in Global Chains: The Causes and Consequences of Export Dynamism in Torreon's Blue Jeans Industry. World Development, 29 (11), 1885-1903.

Banerjee, A., and Munshi, K. (2000). Networks, Migration, and Investment: Insiders and Outsiders in Tirupur's Production Cluster. Mimeo.

Chaudhry, T. (2011). Contracting and Efficiency in the Surgical Goods Cluster of Sialkot, Pakistan. South Asia Economic Journal, 12(1), 91 115.

Dickinson, S. and Ramaseshan, B. (2008). Maximising Performance from Cooperative Marketing: Understanding the Role of Environmental Contexts. Journal of Marketing Management, 24 (5-6), 541 - 566.

Gulati, R. (1995). Does Familiarity Breed Trust? The Implications of Repeated Ties for Contractual Choice in Alliances. The Academy of Management Journal, 38(1), 85 - 112.

Human, S., and Provan, K. (1997). An Emergent Theory of Structure and Outcomes in Small-Firm Strategic Manufacturing Networks. The Academy of Management Journal, 40(2), 368 - 403.

Knorringa, P. (1999). Agra: An Old Cluster Facing the New Competition. World Development, 27 (9), 1587-1604.

Kogut, B. (1988). Joint Ventures: Theoretical and Empirical Perspective. Strategic Management Journal, 9 (4), 319 - 332.

Government of Pakistan, (2010). Industrial Policy, Its Spatial Aspects, and Cluster Development in Pakistan, Vol. 1: Analysis Report of the Industrial Policy 2010. Report prepared for the Ministry of Industries and Production, Government of Pakistan. 
Nadvi, K. (1999). Collective Efficiency and Collective Failure: The Response of the Sialkot Surgical Instrument Cluster to Global Quality Pressures. World Development, 27(9), 1605-1626.

Nadvi, K. (1999). Shifting Ties: Social Networks in the Surgical Instrument Cluster of Sialkot, Pakistan. Development and Change, 30 (b), 141-175.

Saxton, T. (1997). The Effects of Partner and Relationship Characteristics on Alliance Outcomes. The Academy of Management Journal, 40(2), $443-461$.

Schmitz, H. (1999). Responding to Global Competitive Pressure: Local Co-Operation and Upgrading in the Sinos Valley, Brazil. IDS Working Paper 82.

Schmitz, H. and Nadvi, K. (1999). Clustering and Industrialization: Introduction. World Development, 27 (9), 1503-1514.

Small and Medium Enterprise Development Authority (SMEDA), (2001). Government of Pakistan, Surgical Instrument Industry of Pakistan: Issues in Export Growth and Development Draft Report.

Tewari, M., (1999). Successful Adjustment in Indian Industry: the Case of Ludhiana's Woolen Knitwear Cluster, World Development, 27 (9), 1651-1671.

Thompson, T., (2005). Cooperation in Developing Country Industrial Clusters: Marketing in an Age of Globalization. Unpublished PhD Dissertation, University of Maryland College Park. 
Appendix

\section{Sialkot Firm Questionnaire (Selected Questions)}

Name of Firm being interviewed:

\section{Part 1: GENERAL QUESTIONS about interviewed firm:}

1. What is the name of your firm?

2. How many employees did you have in August 2001?

3. When did your firm start to operate?

4. How many different products does your firm manufacture?

5. What percentage of your firm is owned by:

(a) the top manager or his family?

(b) other private individuals?

(c) other private firms?

(d) other $\%$

\section{Part 2: Questions about cooperation and marketing}

6. Does your largest customer

(a) sell the surgical instruments you produce only under their own brand name

(b) sell the surgical instruments you produce only under your company's name

(c) sell some items under their brand name and others under your company's name

7. Does your second largest customer

(a) sell the surgical instruments you produce only under their own brand name

(b) sell the surgical instruments you produce only under your company's name

(c) sell some items under their brand name and others under your company's name

8. Do you currently sell any surgical instruments directly to hospitals? (0) No (1) Yes

If yes, do you use the internet/world wide web to market your products? (0) No (1) Yes 
9. If other firms in the cluster were forming a cooperative to sell surgical instruments directly to hospitals rather than selling to surgical instrument companies in the U.S. and Europe, would you join it?

(0) No (1) Yes (if answer is yes, continue to next part of question, otherwise, go to question 10)

Would you still want to do that if it meant you lost your business relationship with the surgical instrument companies that currently buy from you? (0) No (1) Yes

10. Would you join in a cooperative with other manufacturers in Sialkot to market your products directly to hospitals or doctors rather than selling to surgical instrument companies in the U.S. and Europe if:

(a) the price that hospitals paid for surgical instruments rose 10\%? (0)

No (1) Yes (if answer is no, continue to part (b), otherwise go to question 11)

(b) the price that hospitals paid for surgical instruments rose 25\%? (0)

No (1) Yes (if answer is no, continue to part (c), otherwise go to question 11)

(c) the price that hospitals paid for surgical instruments rose $50 \%$ ? (0)

No (1) Yes (if answer is no, go to question 12, otherwise go to question 11)

11. If the price that hospitals paid for surgical instruments rose and you were considering joining the cooperative, would you still want to join the cooperative if it meant you lost your business relationship with the surgical instrument companies that currently buy from you? (0) No (1) Yes

12. If the minimum quality standards demanded by surgical instrument companies rose, would you join a cooperative with other manufacturers in Sialkot to market your products directly to hospitals? (0) No (1) Yes (if answer is yes, continue to next part of question, otherwise, go to question 13)

Would you still want to join the cooperative if it meant you lost your business relationship with the surgical instrument companies that currently buy from you? (0) No (1) Yes

13. If hospitals were willing to buy surgical instruments directly from Sialkot firms through the internet, would you consider doing that? (0) No (1) Yes (if answer is yes, continue to next part of question, otherwise, go to question 14)

Would you still want to joint the cooperative if it meant you lost your business relationship with the surgical instrument companies that currently buy from you? (0) No (1) Yes 
14. Would you be more likely to join such a cooperative if the other firms joining were mostly large firms? (0) No (1) Yes

15. Would be more likely to join such a cooperative if the other firms joining were mostly small firms? (0) No (1) Yes

16. Additional comments: Has the idea of a cooperative among Sialkot firms to avoid the middleman and sell directly in the U.S. and Europe ever been discussed? What factors would influence your decision?

Part 3: Questions about CUSTOMERS of the interviewed firm:

(The "First Customer" refers to your largest customer at the time your firm started as a private firm.)

\begin{tabular}{lcl}
\hline & First Customer & Newest Customer \\
\hline $\begin{array}{l}\text { 22. How long has he } \\
\text { been a customer? }\end{array}$ & Y Years____Months____Years____Months \\
\hline
\end{tabular}

\section{Part 5: FINAL GENERAL QUESTIONS}

84. How often do you talk with other surgical instrument manufacturers in Sialkot?
(a) daily
(b) weekly
(c) monthly
(d) less frequently / not at all

87. Do you currently receive state or private bank financing? (1) yes (0) no

88. Do you belong to any sort of credit or saving association? (1) yes (0) no 
Appendix

Table 1: Current Marketing Strategies and Interest in Joint Marketing, by Firm Size

\begin{tabular}{|c|c|c|c|c|c|c|}
\hline & $\begin{array}{c}<20 \\
\text { Employees }\end{array}$ & $\begin{array}{c}20-49 \\
\text { Employees }\end{array}$ & $\begin{array}{c}50-149 \\
\text { Employees }\end{array}$ & $\begin{array}{c}150-249 \\
\text { Employees }\end{array}$ & $\begin{array}{c}>250 \\
\text { Employees }\end{array}$ & $\begin{array}{c}\text { Total } \\
\text { (\% of } \\
\text { firms } \\
\text { overall) }\end{array}$ \\
\hline \multicolumn{7}{|c|}{ Current Marketing Strategies } \\
\hline $\begin{array}{l}\text { Sales Under Your Own } \\
\text { Name (current) }\end{array}$ & $50.0 \%$ & $38.9 \%$ & $38.5 \%$ & $85.7 \%$ & $16.7 \%$ & $44.6 \%$ \\
\hline $\begin{array}{l}\text { Any Direct Sales to } \\
\text { Hospitals (current) }\end{array}$ & 25.0 & 33.3 & 38.5 & 28.6 & 16.7 & 30.4 \\
\hline $\begin{array}{l}\text { Internet Marketing } \\
\text { (current) } \\
\text { Interest in Joint Marketing, } \\
\text { Depending on Prices }\end{array}$ & 16.7 & 33.3 & 38.5 & 28.6 & 16.7 & 28.6 \\
\hline Not Interested & $58.3 \%$ & $77.8 \%$ & $61.5 \%$ & $85.7 \%$ & $100.0 \%$ & $73.2 \%$ \\
\hline Yes, if $50 \%$ price increase & 0.0 & 11.1 & 7.7 & 0.0 & 0.0 & 5.4 \\
\hline Yes, if $25 \%$ price increase & 8.3 & 5.6 & 15.4 & 0.0 & 0.0 & 7.1 \\
\hline Yes, if $10 \%$ price increase & 25.0 & 5.6 & 0.0 & 14.3 & 0.0 & 8.9 \\
\hline $\begin{array}{l}\text { Yes, even if no price } \\
\text { increase } \\
\text { Interest in Joint Marketing, if } \\
\text { Higher Quality Standards } \\
\text { Imposed by Current Cust. }\end{array}$ & 8.3 & 0.0 & 15.4 & 0.0 & 0.0 & 5.4 \\
\hline Not interested & $70.0 \%$ & $81.3 \%$ & $76.9 \%$ & $71.4 \%$ & $83.3 \%$ & $76.9 \%$ \\
\hline $\begin{array}{l}\text { Yes, if don't lose current } \\
\text { customers }\end{array}$ & 20.0 & 6.3 & 7.7 & 0.0 & 0.0 & 7.7 \\
\hline $\begin{array}{l}\text { Yes, even if lose current } \\
\text { customers } \\
\text { Interest in Direct Internet } \\
\text { Sales }\end{array}$ & 10.0 & 12.5 & 15.4 & 28.6 & 16.7 & 15.4 \\
\hline Not interested & $50.0 \%$ & $62.5 \%$ & $41.7 \%$ & $50.0 \%$ & $16.7 \%$ & $48.0 \%$ \\
\hline $\begin{array}{l}\text { Yes, if don't lose current } \\
\text { customers }\end{array}$ & 50.0 & 18.8 & 25.0 & 33.3 & 66.7 & 34.0 \\
\hline $\begin{array}{l}\text { Yes, even if lose current } \\
\text { customers } \\
\text { Interest in Joint Marketing, } \\
\text { Size of Other Firms in Co-op }\end{array}$ & 0.0 & 18.8 & 33.3 & 16.7 & 16.7 & 18.0 \\
\hline $\begin{array}{l}\text { More interested if mostly } \\
\text { large firms }\end{array}$ & $25.0 \%$ & $20.0 \%$ & $46.2 \%$ & $42.9 \%$ & $50.0 \%$ & $34.0 \%$ \\
\hline $\begin{array}{l}\text { More interested if mostly } \\
\text { small firms }\end{array}$ & 58.3 & 31.3 & 15.4 & 0.0 & 33.3 & 29.6 \\
\hline
\end{tabular}


Appendix

Table 2: Current Marketing Strategies and Interest in Joint Marketing, by Firm Age

\begin{tabular}{|c|c|c|c|c|c|c|}
\hline & $\begin{array}{c}5 \text { Years or } \\
\text { Less }\end{array}$ & $\begin{array}{l}6-10 \\
\text { Years }\end{array}$ & $\begin{array}{l}11-20 \\
\text { Years }\end{array}$ & $\begin{array}{l}21-35 \\
\text { Years } \\
\end{array}$ & $\begin{array}{l}\text { More than } \\
35 \text { Years }\end{array}$ & $\begin{array}{c}\text { Total } \\
\text { (\%of of } \\
\text { firms } \\
\text { overall) } \\
\end{array}$ \\
\hline $\begin{array}{l}\text { Current Marketing } \\
\text { Strategies } \\
\text { Sales Under Your Own }\end{array}$ & & & & & & \\
\hline $\begin{array}{l}\text { Name (current) } \\
\text { Any Direct Sales to }\end{array}$ & $37.5 \%$ & $75.0 \%$ & $37.5 \%$ & $50.0 \%$ & $16.7 \%$ & $44.6 \%$ \\
\hline $\begin{array}{l}\text { Hospitals (current) } \\
\text { Internet Marketing }\end{array}$ & 37.5 & 12.5 & 43.8 & 22.2 & 33.3 & 30.4 \\
\hline $\begin{array}{l}\text { Internet Marketing } \\
\text { (current) } \\
\text { Interest in Joint Marketing, } \\
\text { Depending on Prices }\end{array}$ & 37.5 & 12.5 & 43.8 & 16.7 & 33.3 & 28.6 \\
\hline Not Interested & $62.5 \%$ & $75.0 \%$ & $75.0 \%$ & $77.8 \%$ & $66.7 \%$ & $73.2 \%$ \\
\hline Yes, if $50 \%$ price increase & 12.5 & 0.0 & 6.3 & 5.6 & 0.0 & 5.4 \\
\hline Yes, if $25 \%$ price increase & 12.5 & 0.0 & 6.3 & 0.0 & 33.3 & 7.1 \\
\hline $\begin{array}{l}\text { Yes, if } 10 \% \text { price increase } \\
\text { Yes, even if no price } \\
\text { increase } \\
\text { Interest in Joint Marketing, } \\
\text { if Higher Quality Standards } \\
\text { Imposed by Current Cust. }\end{array}$ & 12.5 & 12.5 & 12.5 & 11.1 & 0.0 & 8.9 \\
\hline $\begin{array}{l}\text { Not interested } \\
\text { Yes, if don't lose current }\end{array}$ & $71.4 \%$ & $87.5 \%$ & $86.7 \%$ & $70.6 \%$ & $60.0 \%$ & $76.9 \%$ \\
\hline $\begin{array}{l}\text { customers } \\
\text { Yes, even if lose current }\end{array}$ & 14.3 & 0.0 & 0.0 & 17.6 & 0.0 & 7.7 \\
\hline $\begin{array}{l}\text { customers } \\
\text { Interest in Direct Internet } \\
\text { Sales }\end{array}$ & 14.3 & 12.5 & 13.3 & 11.8 & 40.0 & 15.4 \\
\hline Not interested & $42.9 \%$ & $50.0 \%$ & $64.3 \%$ & $43.8 \%$ & $20.0 \%$ & $48.0 \%$ \\
\hline $\begin{array}{l}\text { Yes, if don't lose current } \\
\text { customers }\end{array}$ & 28.6 & 37.5 & 21.4 & 43.8 & 40.0 & 34.0 \\
\hline $\begin{array}{l}\text { Yes, even if lose current } \\
\text { customers } \\
\text { Interest in Joint Marketing, } \\
\text { Size of Other Firms in Co-op } \\
\text { More interested if mostly }\end{array}$ & 28.6 & 12.5 & 14.3 & 12.5 & 40.0 & 18.0 \\
\hline $\begin{array}{l}\text { large firms } \\
\text { More interested if mostly }\end{array}$ & $28.6 \%$ & $37.5 \%$ & $31.3 \%$ & $29.4 \%$ & $60.0 \%$ & $34.0 \%$ \\
\hline small firms & 50.0 & 50.0 & 18.8 & 23.5 & 20.0 & 29.6 \\
\hline
\end{tabular}




\section{Appendix}

Table 3: Summary Statistics

\begin{tabular}{|c|c|c|c|c|c|}
\hline & Mean & Median & Std. Dev. & Min & Max \\
\hline $\begin{array}{l}\text { Number of } \\
\text { Employees }\end{array}$ & 95.54 & 45.5 & 121.45 & 5 & 585 \\
\hline Firm Age & 18.59 & 16.5 & 12.34 & 2 & 53 \\
\hline $\begin{array}{l}\text { Sell Some Products } \\
\text { Under Own Name }(0,1) \text { (dummy) }\end{array}$ & 0.46 & 0 & 0.50 & 0 & 1 \\
\hline $\begin{array}{l}\text { Sell Some Products } \\
\text { Directly to Hospitals }(0,1) \\
\text { (dummy) }\end{array}$ & 0.30 & 0 & 0.46 & 0 & 1 \\
\hline $\begin{array}{l}\text { Would Participate in } \\
\text { Joint Action }(0,1) \text { (dummy) }\end{array}$ & 0.27 & 0 & 0.45 & 0 & 1 \\
\hline $\begin{array}{l}\text { Duration of Trading Relationship } \\
\text { with Oldest Customer (years) }\end{array}$ & 11.55 & 10 & 8.64 & 1 & 40 \\
\hline $\begin{array}{l}\text { Talk at Least Weekly with Other } \\
\text { Producers }(0,1) \text { (dummy) }\end{array}$ & 0.45 & 0 & 0.50 & 0 & 1 \\
\hline Credit Access $(0,1)$ (dummy) & 0.59 & 1 & 0.50 & 0 & 1 \\
\hline
\end{tabular}

